Dr DRAGAN BOGETIĆ, naučni savetnik

Institut za savremenu istoriju

UDK 327(497.1:73)"1975"

Beograd, Trg Nikole Pašića 11

\title{
POSETA DŽERALDA FORDA JUGOSLAVIJI AVGUSTA 1975. I JUGOSLOVENSKO-AMERIČKE NESUGLASICE OKO AKTUELNIH ŽARIŠTA SVETSKE KRIZE*
}

\begin{abstract}
APSTRAKT: U članku je obrađena politička pozadina i sadržina razgovora koji su vodili Josip Broz Tito i američki predsednik Džerald Ford (Gerald Ford) u Beogradu 3. i 4. avgusta 1975. Tim razgovorima prethodilo je ozbiljno pogoršanje jugoslovensko-američkih odnosa zbog oštre jugoslovenske kritike američke politike na Bliskom istoku, Kipru, u Panami i Čileu i nespremnosti američke vlade da podrži zahteve nesvrstanih zemalja u vezi sa restrukturisanjem aktuelnog međunarodnog ekonomskog sistema. Neposredni lični kontakt dvojice državnika u Beogradu i otvorena razmena suprotstavljenih gledišta delimično su doprineli ublažavanju međusobnih animoziteta i premošćavanju razlika koje su opterećivale odnose Jugoslavije i SAD.
\end{abstract}

Ključne reči: Tito, Ford, Jugoslavija, SAD, nesvrstanost, Bliski istok, saradnja, blokovi, Izrael, ekonomska kriza

Sredinom 70-ih godina prošlog veka, Tito i njegovi saradnici su se suočavali sa novim izazovima u međunarodnoj zajednici i novim prilazom supersila rešavanju svetskih problema, koji je potencijalno mogao ugroziti dotadašnju relativno stabilnu međunarodnu poziciju Jugoslavije i njenu nesvrstanu politiku. Bipolarni detant SAD i SSSR svodio se na svojevrsni monopol dve sile $u$ međunarodnim odnosima u rešavanju osnovnih međunarodnih pitanja sa pozicija sile, međusobno priznatih i uvaženih interesa, uticajnih sfera, ravnoteže nuklearnog naoružanja i dogovaranja, što se sve zajedno približavalo Kisindžerovom (Kissinger) idealu međunarodnog poretka koji počiva na ravnoteži i konsenzusu sile i legitimiteta najmoćni-

* Rad je deo projekta Srpsko društvo u jugoslovenskoj državi u 20. veku: između demokratije i diktature (177016), koji finansira Ministarstvo prosvete, nauke i tehnološkog razvoja Republike Srbije. 
jih. Takav sistem ravnoteže snaga u svetu bio je u direktnoj koliziji sa konceptom nesvrstavanja, ali i u koliziji sa jugoslovenskim nastojanjima da $u$ rešavanju ključnih međunarodnih problema ravnopravno učestvuju sve države. Zvaničnici iz Beograda su strahovali od mogućeg dogovora između SAD i SSSR-a na račun Jugoslavije, koji bi išao u prilog sovjetskim hegemonističkim aspiracijama prema Jugoslaviji. ${ }^{1}$

Jugoslovenska sumnjičavost i podozrenje u pogledu aktuelnog spoljnopolitičkog kursa SAD nisu bili bez osnova. Doduše, prilaz Fordove administracije nesvrstanom svetu, ${ }^{2}$ a samim tim i politici Jugoslavije, sredinom 70-ih godina razlikovao se od prethodnih administracija, pre svega zbog ispoljavanja daleko većeg aktivizma, dinamičnosti, angažovanosti i agresivnosti prema tom konceptu. Fordova administracija je bila prva američka administracija koja je veliki deo svojih spoljnopolitičkih aktivnosti usredsredila na sam pokret nesvrstanosti, posebno na delovanje tog pokreta $u$ Ujedinjenim nacijama i u drugim međunarodnim organizacijama. ${ }^{3}$ Međutim, okosnicu ovakve američke međunarodne strategije činila je teza predsednika Forda i državnog sekretara SAD Kisindžera - o „svrstanosti nesvrstanih" i njihovom uključivanju u "treći blok", koji je svoju političku i ekonomsku oštricu uperio protiv razvijenih zapadnih zemalja. Stoga su američki zvaničnici sredinom 70-ih godina opravdavali politiku direktne, čak militantne konfrontacije sa nesvrstanima, pribegavajući otvoreno politici sile, pritiska i ucene, pokušavajući na sve načine da marginalizuju, oslabe i politički diskredituju pokret nesvrstanosti. ${ }^{4} \mathrm{U}$ tom duhu su iz Beograda upućivane oštre kritike na račun „američkog imperijalizma“ kao generatora državnih udara i destabilizacije političkih režima u pojedinim nesvrstanim zemljama ili zemljama koje su u svojstvu posmatrača učestvovale na samitima nesvrstanih (državni udar u Čileu - 11. septembra 1973. i na Kipru 15. jula 1974; sukob oko suvereniteta na Panamskom kanalu tokom 70-ih godina). Manevri američke Šeste flote i italijanskih oružanih snaga u sever-

${ }^{1}$ Robert D. Šulcinger, Američka diplomatija od 1900. godine, Beograd 2011; Dušan Nikoliš, SAD. Strategija dominacije, Beograd 1985; Dragan Bogetić, Američke analize budućnosti Jugoslavije posle Tita s početka 70-ih godina, Tokovi istorije, br. 1/2012, Beograd 2012, 159-174; Josip Moćnik, United States-Yugoslav relations, 1961-80: The Twilight of Tito's era and the Role of Ambassadorial Diplomacy in the Making of America's Yugoslav Policy, Bowling Green, Ohio 2008; Ivo Visković, Odnosi Jugoslavije i Sjedinjenih Američkih Država, Jugoslovenski pregled, godina XXXII, 1, 1988, 23-45.

2 Džerald Ford je 9. avgusta 1974. preuzeo funkciju predsednika SAD, posle ostavke predsednika Ričarda Niksona (Richard Nixon) uslovljene aferom Votergejt.

${ }_{3}^{3}$ AJ, KPR, I-5-b/104-20. Ocene američke spoljne politike.

${ }^{4}$ R. Vukadinović, Američka vanjska politika i nesvrstavanje, Međunarodna politika, br. 594, 1975; D. Nikoliš, n. d., H. Kissinger, A Just Consensus, A Stable Order, A Durable Pea$c e$, An Address made before the 28th Session of United Nations General Assembly, September 24, 1973, Department of State Bulletin, October 15, 1973, p. 470. 
nom Jadranu krajem marta 1974, organizovani upravo u momentu kada dolazi do obnavljanja Tršćanske krize, dodatno su doprineli zaoštravanju jugoslovensko-američkih odnosa. ${ }^{5}$

U ovo vreme, međunarodni odnosi su obogaćeni jednom novom komponentom. Osim i dalje prisutne konfrontacije Istok-Zapad, tokom 70ih godina u prvi plan sve više izbija konfrontacija Sever-Jug, koja u nekim segmentima postaje najopasniji izvor zategnutosti u međunarodnim odnosima. Insistiranje nesvrstanih zemalja na ravnomernijoj raspodeli svetskog bogatstva i ublažavanju sve većeg jaza koji je delio bogati Sever od siromašnog Juga, naišlo je na izuzetno negativan prijem industrijski razvijenih zemalja. Iako su zapadne sile u prvom momentu ispoljile određenu kooperativnost $\mathrm{u}$ tom kontekstu, ${ }^{6}$ dalje forsiranje radikalnih ekonomskih zahvata na globalnom planu od strane nesvrstanih zemalja rezultiralo je oblikovanjem strategije razvijenih zemalja koja je bila ne samo konzervativno-egoistična i odbranaška, nego i izrazito agresivna i ratoborna prema svim protagonistima suštinske transformacije postojećeg sistema međunarodnih odnosa. ${ }^{7}$

Pošto je Jugoslavija bila jedna od zemalja koje su posebno energično zagovarale ovu ideju, zvaničnici u Vašingtonu su sa sve većom podozrivošću preispitivali njenu nesvrstanu politiku. U Stejt departmentu je stav Jugoslavije - da je postojeći sistem međunarodnih ekonomskih odnosa skrojen po meri najbogatijih kapitalističkih zemalja i da zato reprodukuje odnose dominacije i eksploatacije imanentne samom biću kapitalizma - tumačen kao tipičan ideologiziran pogled komunističkih doktrinara, koji ne mogu u potpunosti da se oslobode i distanciraju od sovjetske propagande. U tom smislu, „iako su Jugosloveni pokazali novu svest i razumevanje za osetljive

${ }^{5}$ Foreign Relations of the United States (FRUS), 1969-1976, Volume E-15, Part 1, Documents on Eastern Europe, 1973-1976, Yugoslavia, doc 64, 66, 67; AJ, KPR, I-3-a/107211. Informacija o odnosima Jugoslavije i Sjedinjenih Američkih Država; Isto, 107-212. Neki elementi spoljne politike SAD; Isto, 107-215. Neki aktuelni aspekti međunarodnih ekonomskih odnosa i politike $S A D$; Isto. Informacija o američkoj spoljnoj politici i unutrašnjim pitanjima u SAD; FRUS, 1969-1976, Volume E-15, Part 1, Documents on Eastern Europe, 1973-1976, Yugoslavia, doc 64, 66, 67.

${ }^{6}$ Razvijene zemlje su prihvatile inicijativu nesvrstanih zemalja (uobličenu na Samitu nesvrstanih u Alžiru, septembra 1973) o održavanju posebnog zasedanja Generalne skupštine UN posvećenog problemima ekonomskog razvoja. U tom duhu je u proleće 1974. održano Šesto specijalno zasedanje GS UN. To je bilo prvo vanredno zasedanje svetskog parlamenta posvećeno isključivo ekonomskoj problematici - sve prethodna vanredna zasedanja bila su posvećena političkim pitanjima. Na Šestom zasedanju Generalne skupštine usvojena je Deklaracija o uspostavljanju novog međunarodnog ekonomskog poretka i program akcije. - Dragan Bogetić, Nesvrstanost i novi međunarodni ekonomski poredak, Marksistička misao, br. 1, Beograd 1979, 159-176.

${ }^{7}$ FRUS, 1969-1976, Volume E-15, Part 1, Documents on Eastern Europe, 19731976, Yugoslavia, doc 67; D. Nikoliš, n. d., 70-71. 
oblasti u američkoj spoljnoj politici“, treba shvatiti da će „jugoslovenska vlada uvek biti na komunističkoj liniji“; „da je Jugoslavija slobodna i nezavisna komunistička zemlja koja je ipak anti-imperijalistički nastrojena". Pored toga, procenjeno je da je celokupna spoljnopolitička strategija Jugoslavije u funkciji njenih nastojanja da zadrži i ojača svoju lidersku poziciju u pokretu nesvrstanosti: „Na primer, kada je pokret postao radikalniji, Jugosloveni su u obavezi da preuzmu neke radikalnije stavove kako bi održali svoju ulogu vođstva". ${ }^{8}$

U Vašingtonu je, međutim, takođe ocenjeno da američki „osnovni nacionalni interesi zahtevaju da Jugoslavija ostane van Varšavskog pakta, i da je ovaj cilj, sam po sebi, dovoljan razlog za Sjedinjene Države da održavaju dobre odnose sa Jugoslavijom. Kamen temeljac naših odnosa treba da bude da obe strane odražavaju spremnost da razgovaraju i uvažavaju pozicije druge strane sa poštovanjem" . ${ }^{9}$ Premda Jugoslavija često zastupa stavove koji su u koliziji sa stavovima SAD i povremeno indirektno ide na ruku politici koju zastupa Moskva, „ovi faktori nisu narušili ravnotežu. Jugoslavija je i dalje pro-zapadno orijentisana u svojim trgovinskim interesima; još uvek su veoma veliki zapadni krediti prisutni u zemlji, a Jugosloveni su odlučni da budu slobodni i nesvrstani“. ${ }^{10}$

Pragmatizam u percepciji poželjnog kursa spoljnopolitičke strategije u sklopu nastojanja za otklanjanjem aktuelnih nesuglasica u jugoslovensko-američkim odnosima, bio je sve prisutniji i u Beogradu. Tito i njegovi saradnici bili su svesni da bez poboljšanja odnosa sa SAD nije mogućno voditi uravnoteženu nesvrstanu politiku, niti realizovati aktuelne ekonomske prioritete na unutrašnjem planu. ${ }^{11}$ Bez američkih kredita i američke podrške $u$ svetskim finansijskim institucijama teško je bilo realizovati ambiciozne investicione projekte. S druge strane, jugoslovensko rukovodstvo nije bilo ravnodušno ni na sve otvorenije političke i subverzivne akcije

${ }^{8}$ FRUS, 1969-1976, Volume E-15, Part 1, Documents on Eastern Europe, 19731976, Yugoslavia, doc 69

Isto; Dragan Bogetić, Američke analize budućnosti Jugoslavije posle Tita s početka 70-ih godina, Tokovi istorije, br. 1/2012, Beograd 2012, 159-174.

${ }^{10}$ FRUS, 1969-1976, Volume E-15, Part 1, Documents on Eastern Europe, 19731976, Yugoslavia, doc 67.

${ }^{11}$ Robna razmena Jugoslavije sa SAD 1974. godine iznosila je 670 miliona dolara, a tokom prve polovine 1975. dostigla je iznos od 287 miliona dolara. Samim tim Sjedinjene Države su zauzimala visoko četvrto mesto u ukupnoj jugoslovenskoj trgovinskoj razmeni sa inostranstvom (posle SSSR-a, Italije i SR Nemačke). Jugoslavija je u trgovinskim odnosima sa SAD imala isti tretman nedeskriminacije (status „najpovlašćenije nacije“) kao i zapadnoevropske države. Za realizaciju jugoslovenskih razvojnih projekata od izuzetnog značaja bili su povoljni krediti američke Eksport-import banke i međunarodnih finansijskih institucija u kojima su SAD imale veliki uticaj. - AJ, KPR, I-3-a/107-215. Međunarodna ekonomska pitanja. 
informbirovaca u Jugoslaviji i grananje njihove mreže van jugoslovenske teritorije. $^{12}$ Radi uspostavljanja kakve-takve ravnoteže $u$ vojnoj saradnji sa Istokom i Zapadom, Jugoslavija je morala da poboljša svoje odnose sa Pentagonom i obezbedi isporuku adekvatne vojne opreme iz SAD. Zadržavanje jednostrane zavisnosti od isporuke naoružanja i obuke vojnih kadrova u Sovjetskom Savezu nosilo je ozbiljne rizike i kosilo se sa intencijom proklamovane nezavisne nesvrstane politike.

Imajući u vidu da SAD ostaju jedan od ključnih jugoslovenskih spoljnopolitičkih partnera, jugoslovenski političari su bili generalno saglasni da treba preduzeti hitne mere u cilju poboljšanja odnosa sa ovom silom i u tu svrhu pokrenuti inicijative za organizovanje što češćih ličnih kontakata rukovodećih ličnosti dveju zemalja. Pošto je i u Vašingtonu prevagnuo sličan stav - sredinom 1974. i početkom 1975. godine - dolazi do sve češće razmene poseta delegacija iz SAD i Jugoslavije i sve češćih direktnih susreta i razgovora visokih zvaničnika dveju zemalja. Poseban značaj u tom kontekstu imala je poseta američkog državnog sekretara i savetnika za nacionalnu bezbednost, Henrija Kisindžera, 4. novembra 1974. i poseta predsednika jugoslovenske vlade Džemala Bijedića Vašingtonu, od 19. do 21. marta $1975 .^{13}$

Rezultat žive diplomatske aktivnosti i unapređenja političke saradnje Jugoslavije i SAD bila je zvanična poseta američkog predsednika Džeral-

${ }^{12}$ Krajem septembra 1974. u Beogradu je objavljeno saopštenje Saveznog javnog tužilaštva u vezi sa okončanjem sudskog postupka protiv pripadnika ilegalne grupe koja je optužena da je u saradnji sa informbirovskim emigrantima iz inostranstva pripremala subverzivne delatnosti protiv ustavnog poretka SFRJ (Borba, 20. septembar 1974). Radilo se o grupi koja je na sastanku u Baru, na dan kada je počeo napad na Jugoslaviju u Drugom svetskom ratu, 6. i 7. aprila 1974, formirala svoju partiju - Novu KPJ i izabrala generalnog sekretara i politička tela: Centralni komitet, Politbiro, Nadzornu i Revizionu komisiju, redakciju lista Iskra, a potom usvojila Statut i izdala Proglas. (Srđan Cvetković, Neoibeovci. Obračun sa prosovjetskom opozicijom u SFRJ i kidnapovanje Vlade Dapčevića, Istorija 20. veka, 2, Beograd 2012, 147-164). U Materijalu jugoslovenske Službe državne bezbednosti, ocenjeno je „da se delatnost informbiroovske emigracije odvija uz znanje obaveštajne službe Sovjetskog Saveza, uključujući njenog šefa, člana Politbiroa KPSS, Andropova, kao i obaveštajnih službi Bugarske, Čehoslovačke i nekih drugih istočno-evropskih zemalja. Ne može se, takođe, ni isključiti mogućnost da su u određenoj meri sa njom upoznati i neki drugi faktori ovih zemalja“. AJ, KPR, I-3-a/101-153. Neke karakteristike novije obaveštajne i druge subverzivne aktivnosti SSSR-a prema Jugoslaviji i Informbiroovaca u zemlji i inostranstvu. AJ, KPR, I-5-5/99-26. Informacija o jugoslovensko-sovjetskim odnosima sa osvrtom na neka aktuelna pitanja politike KPSS u međunarodnom radničkom pokretu.

${ }^{13}$ AJ, KPR, I-3-1/107-212. Osnovni ciljevi Kisindžerove posete Jugoslaviji; isto. Beleška o razgovoru Predsednika SIV Džemala Bijedića sa Državnim sekretarom SAD dr H. Kisindžerom, 4. XI 1974; isto. Zabeleška o razgovoru Predsednika SFRJ J. B. Tita sa Državnim sekretarom SAD dr H. Kisindžerom, održanim 4. XI 1974. godine; AJ, KPR, I-5-c/23. Poseta predsednika SIV-a Vašingtonu; AJ, KPR, I-5-b/104-20. Informacija o razgovorima predsednika SIV-a Džemala Bijedića sa Fordom na ručku u Beloj kući, 19. marta 1975. 
da Forda Beogradu, avgusta 1975. Ta poseta je imala burnu predistoriju, uslovljenu stalnom smenom uspona i padova $\mathrm{u}$ jugoslovensko-američkim odnosima sredinom 70 -ih godina.

Kao dobru priliku za iniciranje posete, jugoslovenska strana iskoristila je razmenu kurtoaznih poruka Tita i Forda u momentu kada je Ford preuzeo funkciju predsednika SAD, avgusta 1974. Odmah po preuzimanju predsedničke funkcije, Džerald Ford je uputio srdačno pismo Titu, u kome mu je naglasio svoju odlučnost da će „nastaviti politiku bliskih odnosa i uzajamno korisne saradnje između naše dve zemlje" $i$ učiniti sve što je $u$ njegovoj moći da „ojača veze“ koje su stvorene pod vođstvom predsednikâ Niksona i Tita. „Nalazimo se na važnoj prekretnici u istoriji i imamo priliku da ojačamo bezbednost i prosperitet svih zemalja u Evropi. Svestan sam značaja nezavisnosti Jugoslavije i njenog nesvrstanog položaja i možete biti uvereni da će principi iznešeni u Zajedničkoj izjavi predsednika Niksona i Vas iz 1971. godine nastaviti da i dalje čine okvir naših odnosa". ${ }^{14}$

U kratkom odgovoru na pismo predsednika Forda, 21. avgusta 1974, Tito se zahvalio na „prijateljskoj poruci“ i izrazio svoje zadovoljstvo zbog spremnosti američkog predsednika da doprinese poboljšanju odnosa i proširivanju saradnje sa Jugoslavijom. Napominjući da su „značajno mesto u unaprijeđenju odnosa između naše dvije zemlje“ imali njegovi „kontakti sa uvaženim ranijim predsjednicima Sjedinjenih Američkih Država“, Tito je ukazujući na „korisnost takve prakse“ uputio zvaničan poziv Fordu da poseti Jugoslaviju, „u vrijeme koje Vam bude odgovaralo“. ${ }^{15}$

Iako je pozitivno reagovao na Titovo pismo, Ford se nije izjašnjavao $\mathrm{u}$ vezi sa predlogom da poseti Jugoslaviju. To se, pre svega, može objasniti činjenicom da je upravo u ovo vreme ponovo došlo do ozbiljnog zaoštravanja u jugoslovensko-američkim odnosima zbog državnog udara na Kipru i nasilne smene lidera te države, arhiepiskopa Makariosa. Jugoslavija je za prevrat na Kipru optuživala američku službu CIA i snage NATO-a, što je izuzetno negativno primljeno u Vašingtonu i protumačeno kao „neočekivani gest neprijateljstva sa jugoslovenske strane“ ${ }^{\text {“ }}{ }^{16}$

${ }^{14}$ AJ, KPR, I-1/1120. Poruka Predsednika SAD Geralda R. Forda Predsedniku Republike Josipu Brozu Titu, 10. avgust 1974.

${ }^{15}$ AJ, KPR, I-1/1120. Odgovor Predsedniku Republike Josipa Broza Tita, Predsedniku $S A D$ G. R. Fordu, 21. avgust 1974.

${ }^{16}$ AJ, KPR, I-5-b/104-19. Kiparska kriza - viđena u Vašingtonu; isto. Zabeleška o razgovoru potpredsednika SIV-a i saveznog sekretara za inostrane poslove M. Minića sa ambasadorom M. Tun-om na dan 23. avgusta 1974. godine; isto. Iz zabeleške o razgovoru zamenika saveznog sekretara L. Mojsova sa ambasadorom SAD u Beogradu M. Tunom na dan 18. septembra 1974; isto. Telegram ambasade SFRJ u Vašingtonu, 13. septembar 1974. godine; AJ, KPR, I1/1121. Poruka Predsednika Republike Josipa Broza Tita, Predsedniku SAD Geraldu R. Fordu, 6. septembar 1974. U Jesenicama, 12. septembra 1974, Tito je, govoreći o pozadini puča na 
Na Titovo pismo, Ford je odgovorio tek 13. januara 1975. i tom prilikom prihvatio poziv da poseti Jugoslaviju, ne precizirajući tačno datum kada bi to bilo realizovano. Na ovaj korak američkog predsednika u velikoj meri je uticao državni sekretar Henri Kisindžer. On je, 10. januara 1975, iznoseći svoje stavove u formi posebnog memoranduma, skrenuo pažnju Fordu da su jugoslovensko-američke nesuglasice oko kiparskog pitanja uglavnom svedene na prihvatljivu formu tokom Kisindžerove posete Beogradu 4. novembra 1974. i da je krajnje vreme da se Ford izjasni o Titovom pozivu da poseti Beograd. „Odgovor bi u ovom trenutku bio dobro tempiran zbog nedavnih događaja u Jugoslaviji koji doprinose pozitivnijem stavu Jugoslavije prema SAD. U septembru [1974. godine - D. B.], Tito je otkrio da je SSSR ponovo uključen u unutrašnje rasprave u Jugoslaviji. Subverzivne sovjetske aktivnosti, kroz neku vrstu zavere kominformista, ${ }^{17}$ razljutile su Tita i potvrdile najgore jugoslovenske strahove da titoizam ostaje neprihvatljiv za Sovjete koji će nastaviti njegovo podrivanje, što je u određenom stepenu ohrabrilo Jugoslaviju da pokuša dalje širenje odnosa sa Zapadom“. Kisindžer je u svom memorandumu procenjivao da u novonastaloj situaciji Tito i jugoslovenski rukovodioci „pridaju veliku pažnju Vašoj poseti Jugoslaviji“ i da bi oni „cenili Vaš lični sastanak sa Titom kao novo i jasno američko priznavanje jugoslovenske nezavisnosti i nesvrstavanja. Meni se čini da bi takva poseta pozitivno doprinela Vašim spoljnopolitičkim ciljevima, ne samo prema Jugoslaviji, već i zarad stabilnosti u odnosima Istoka i Zapada" ${ }^{18}$

Prihvatajući Kisindžerovu argumentaciju predsednik Ford je, 13. januara 1975, uputio pismo Titu u kome je prihvatio poziv da poseti Jugoslaviju. „Važno je da Sjedinjene Države i Jugoslavija vode stalni dijalog o problemima od zajedničkog interesa. U tom duhu ja sa zadovoljstvom prihvatam Vaš poziv da posetim Jugoslaviju. Unapred se radujem što ćemo lično razmeniti gledišta o odnosima SAD - Jugoslavija, kao i o važnim međunarodnim pitanjima, a naročito o izgledima za mir i stabilnost u svetu. Iako

Kipru, izjavio: „Taj puč su organizovali CIA, grčka vojna hunta i Atlantski pakt. Trebalo je ubiti Makariosa, jer je Kipar bio nesvrstana zemlja, a Makarios je jedan od osnivača politike nesvrstanosti. Trebalo je njega maknuti i pretvoriti Kipar u bazu Atlantskog pakta“. - Josip Broz Tito, Nezavisnost i savremeni svet. Tom 2, Beograd 1982, 505.

${ }^{17}$ Srđan Cvetković, Neoibeovci. Obračun sa prosovjetskom opozicijom u SFRJ i kidnapovanje Vlade Dapčevića, Istorija 20. veka, 2, Beograd 2012, 147-164; AJ, KPR, I-3-a/101153. Neke karakteristike novije obaveštajne i druge subverzivne aktivnosti SSSR-a prema Jugoslaviji i Informbiroovaca u zemlji i inostranstvu. AJ, KPR, I-5-5/99-26. Informacija o jugoslovensko-sovjetskim odnosima sa osvrtom na neka aktuelna pitanja politike KPSS u međunarodnom radničkom pokretu.

${ }^{18}$ FRUS, 1969-1976, Volume E-15, Part 1, Documents on Eastern Europe, 19731976, Yugoslavia, doc 72. Memorandum From the President's Assistant for National Security Affairs (Kissinger) to President Ford, Washington, January 10, 1975. 
je suviše rano da predložim konkretne datume, ja ću sa zadovoljstvom odrediti sa Vama vreme koje bude obostrano povoljno za posetu“ " ${ }^{19}$

Datum posete predsednika Forda Jugoslaviji orijentaciono je utvrđen tokom razgovora jugoslovenskog premijera Džemala Bijedića i Džeralda Forda, u Vašingtonu 19. marta 1975. Bijedićev domaćin je tom prilikom rekao „da oni rade na tome da do posete dođe tokom ove godine i da je njihova namera da posle sastanka, koji će se u okviru Konferencije o evropskoj saradnji održati krajem juna ili početkom jula, posete neke zemlje Evrope, među kojima i Jugoslaviju“. ${ }^{20}$

Fordova prva poseta Evropi otkako je postao predsednik SAD, otpočela je njegovim dolaskom u Brisel na samit NATO-a, 28. i 29. maja 1975. Potom je 31. maja stigao u Madrid. Fordovi razgovori sa ozloglašenim španskim diktatorom Franciskom Frankom i njegova uporna nastojanja da ubedi svoje zapadne saveznike da podrže prijem Španije u NATO, a da se iz te zapadne alijanse odstrani levičarski nastrojena Portugalija nisu baš pozitivno primljeni u jugoslovenskim političkim krugovima, uprkos evidentnom zadovoljstvu zvaničnika iz Beograda zbog Fordove skore posete Jugoslaviji. ${ }^{21}$ Daleko pozitivnije je u Jugoslaviji ocenjena njegova poseta Austriji i razgovori koje je vodio u Salzburgu, 1. i 2. juna sa Sadatom oko razrešenja krize na Bliskom istoku i u Rimu u vezi sa intenziviranjem napora evropskih zemalja u pravcu eliminisanja kriznih žarišta $u$ svetu. Uoči otpočinjanja završne faze Konferencije o evropskoj bezbednosti i saradnji u Helsinkiju (održane od 30. jula do 1. avgusta 1975), Ford je posetio Poljsku i SR Nemačku, a posle ove konferencije, doputovao je u Rumuniju. Potom je došao red i na Jugoslaviju, čime je okončana njegova evropska turneja.

Specijalni avion američkog predsednika, „Duh 76“, u pratnji još šest drugih aviona za raznovrsnu logističku podršku, doleteo je iz Bukurešta na Beogradski aerodrom 3. avgusta, tačno u 17.20 časova (kako je predviđeno $\mathrm{u}$ ranije precizno sačinjenoj satnici ministarstava spoljnih poslova dveju država). Predsednika Forda, koji je u Beograd doputovao sa suprugom, sinovima i velikim brojem saradnika, dočekali su na aerodromu Tito i Jovanka Broz i najviši jugoslovenski zvaničnici. Posle pozdrava sa domaćinom i obilaska počasne garde, Ford je izrazio svoje posebno

${ }^{19}$ AJ, KPR, I-1/1122. Poruka Predsednika SAD Geralda R. Forda, predsedniku Republike Josipu Brozu Titu, 13. januar 1975

${ }^{20}$ AJ, KPR, I-5-c/23. Poseta predsednika SIV-a Vašingtonu; AJ, KPR; I-5-b/104-20. Informacija o razgovorima predsednika SIV-a Džemala Bijedića za vreme posete $S A D$. Iz razgovora sa predsednikom SAD Fordom na ručku u Beloj kući, 19. marta 1975.

${ }^{21}$ AJ, KPR, I-5-b/104-20; Borba, 1. jun 1975; Godišnjak Instituta za međunarodnu politiku i privredu, 1975, Beograd 1976. 
zadovoljstvo što je ponovo u Jugoslaviji ${ }^{22}$ i podvukao da je uveren da će razgovori sa Titom „dati pozitivan doprinos međunarodnom miru, saradnji i bezbednosti“. Istakao je značaj tih razgovora posle Konferencije o evropskoj bezbednosti i saradnji u Helsinkiju na kojoj je učestvovao zajedno sa predsednikom Titom „koji uživa istinsko poštovanje u SAD i čitavom svetu kao jedan od najvećih državnika u periodu posle Drugog svetskog rata". ${ }^{23}$

Ulice kojima su prolazila dva predsednika bile su ukrašene zastavama dveju zemalja, upadljivo velikim portretima Tita i Forda, transparentima kojima se pozdravlja jugoslovensko-američko prijateljstvo i želi dobrodošlica visokom gostu. Iako je bila nedelja, na trotoarima se okupio veliki broj Beograđana kojima su dvojica predsednika mahala iz otvorenog automobila. Sve to predstavljalo je dobar uvod za razgovore Tita i Forda, koji su u večernjim satima (od 19.35 do 21 h) vođeni u zgradi Saveznog izvršnog veća.

$\mathrm{Na}$ samom početku razgovora Tito je izrazio zadovoljstvo što mu se ukazala prilika da pozdravi američkog predsednika i razmeni mišljenje sa njime i njegovim saradnicima u Beogradu. Rekao je da mu je žao što na raspolaganju imaju suviše malo vremena, ali da se nada da će Ford u bližoj budućnosti ponovo posetiti Jugoslaviju. Ford je, zahvaljujući se Titu na dobrodošlici, napomenuo da je i njemu žao što poseta ne traje duže i da bi se i on i njegova supruga "rado vratili i uživali u lepotama Jugoslavije". ${ }^{24}$

Kako su glavni razgovori dvojice predsednika trebali da se vode narednog dana, Tito je, uz napomenu: „Nemamo mnogo vremena večeras“, predložio da se akcenat stavi na neka pitanja koja se tiču budućnosti međunarodnih odnosa i bilateralne saradnje. Pošto je Bliski istok „najproblematičnija tačka“, Tito je predložio da se razmatranje tog pitanja odloži za sutra. Osvrnuo se ukratko na rezultate nedavno održane Konferencije o evropskoj bezbednosti i saradnji u Helsinkiju i postavio pitanje kako ubuduće unaprediti sigurnost u svetu. Smatrao je da postoji određena veza između Konferencije u Helsinkiju i aktuelnih pregovora dveju supersila o razoružanju („Redukcija naoružanja svakako pripada Helsinškom koncep-

${ }^{22}$ Džerald Ford je od 12. do 20. septembra 1963. učestvovao na 52. konferenciji interparlamentarne unije, u Beogradu, kao član američke delegacije. - Hronika međunarodnih događaja 1963, Beograd 1964, 160A; AJ, KPR, I-3-a/107-215.

${ }^{23}$ Borba, 4. avgust 1975.

${ }^{24}$ AJ, KPR, I-3-1/107-215. Stenografske beleške sa razgovora Predsednika Republike Josipa Broza Tita sa Predsednikom SAD, Njegovom ekselencijom gospodinom Geraldom R. Fordom, održanih 3. avgusta 1975. u Beogradu; FRUS, 1969-1976, Volume E-15, Part 1, Documents on Eastern Europe, 1973-1976, Yugoslavia, doc 73. Memorandum of Conversation, Belgrade, August 3, 1975. 
tu“). ${ }^{25}$ Pošto jugoslovenska strana vrlo malo zna o tim pregovorima „sem da su se zaglavili“", Tito je želeo da od sagovornika čuje nešto više o njihovom stvarnom domašaju. Ford se složio sa Titom da tu nije bilo mnogo progresa ( „u ćorsokaku smo“) i da se sve svelo na čisto „tehničke pregovore“, iako su Amerikanci želeli da doprinesu suštinskom iskoraku u pogledu „redukcije naoružanja“. Po njemu, problem je u tome što je „do sada svaka strana predložila razoružanje druge“. Pa ipak, Ford je istakao da je „umereni optimista“ oko krajnjeg ishoda pregovora: „Uveravam Vas da ćemo dati sve od sebe. Imamo formulu i pokušaćemo prodor. Mislim da će duh Helsinkija pogurati pregovore napred“. ${ }^{26}$

Tito je, podržavajući mišljenje svog sagovornika o „pozitivnom uticaju Helsinškog koncepta" na rešavanje ključnih međunarodnih problema, izneo svoje viđenje uloge naredne konferencije o evropskoj bezbednosti, koja će biti održana u Beogradu tokom 1977. godine. Pohvalio se svom gostu: „Sve međunarodne konferencije održane u Beogradu su bile uspešne. Naprimer, prva konferencija nesvrstanih". ${ }^{27}$

${ }^{25}$ Pregovori SAD i SSSR o ograničavanju strateškog naoružanja, poznati pod nazivom SALT (Strategic Arms Limitation Talks), predstavljali su važnu tekovinu bipolarnog detanta tokom 70-ih godina. Dve sile su tokom 1972. sklopile određene sporazume o kontroli odbrambenog naoružanja (SALT I), a sada je trebalo postići dogovor o ograničavanju ofanzivnog naoružanja (SALT II). Ti novi pregovori odvijali su se u dve faze: prva je trajala od 31. januara do 7. maja 1975, a druga je otpočela 2. jula i trebalo je da bude završena do kraja 1975. Problemi su nastali kada se moralo pristupiti konkretizaciji i preciziranju vrsta vojne opreme i naoružanja koje će biti podvrgnuto ugovornim ograničenjima i utvrđivanju ustrojstva sistema kontrole sprovođenja odredbi budućeg sporazuma. Prvi problem je velikim delom proizilazio iz činjenice da su dve sile u toku razvoja svojih vojnih potencijala težište stavljale na različite vrsta naoružanja shodno svojim vojno-strateškim koncepcijama. U tom smislu, pregovarači su odbijali da se u ofanzivno naoružanje uvrste i ograničenju podvrgnu najsavremeniji tipovi sopstvenog oružja koje njihov rival nije posedovao, a istovremeno pokušavali su da nametnu suprotnu logiku kada se radi o novom vojnom arsenalu druge strane. Pošto je trebalo postići vrlo precizna kvantitativna i kvalitativna ograničenja razmatrane vojne tehnike, svaka reč i svaka brojka su oprezno vagani i bili predmet opsežnih rasprava kojima se uopšte nije nazirao kraj. U pogledu kontrole sprovođenja budućeg sporazuma, problem je bio u tome što se za SALT II nije mogao primeniti sistem kontrole nacionalnim sredstvima, korišćen kod prethodnog sporazuma. Takav sistem, kada je reč o sofisticiranoj ofanzivnoj vojnoj tehnologiji, ne bi bio pouzdan, jer ne bi mogao da registruje čitav niz tehničkih inovacija. Mada su se pregovarači oko toga u potpunosti složili, nisu nikako mogli da se dogovore o mogućoj alternativi. - Godišnjak 1975, Beograd 1976, 8-11, 153-157; Radovan Vukadinović, Nuklearne strategije supersila, Zagreb 1985.

${ }^{26}$ AJ, KPR, I-3-1/107-215. Stenografske beleške sa razgovora Predsednika Republike Josipa Broza Tita sa Predsednikom SAD, Njegovom ekselencijom gospodinom Geraldom R. Fordom, održanih 3. avgusta 1975. u Beogradu; FRUS, 1969-1976, Volume E-15, Part 1, Documents on Eastern Europe, 1973-1976, Yugoslavia, doc 73. Memorandum of Conversation, Belgrade, August 3, 1975.

$$
27 \text { Isto. }
$$


Ford je na samo pominjanje nesvrstanih nezadovoljno uzvratio: „Sada su veći nego oba bloka. To je sada najveći blok... Mislim da podela sveta na blokove nije najbolji način za rešavanje problema. U današnjem svetu, ne može biti konfrontacije i vojne aktivnosti kakvu smo poznavali tokom Vaše i moje mladosti. Ja ću se posvetiti eliminaciji tih izvora sukoba koji mogu voditi do vojne konfrontacije. To će biti naša orijentacija“. ${ }^{28}$

Tito i jugoslovenski rukovodioci koji su učestvovali u razgovoru sa Fordom energično su se suprotstavili oceni američkog predsednika da je pokret nesvrstanosti treći blok i da su nesvrstane zemlje izazvale novu vrstu konfrontacija i sukoba u svetu. Prvi je reagovao Džemal Bijedić: „Ne, to nije blok", a potom se umešao i Tito, uz istu konstataciju: „Da, to nije blok“. Kardelj je otišao još dalje i upozorio Forda: „Mnogo zavisi od vas da ne bude blok. Treba razgovarati, a ne konfrontirati se". Da su Sjedinjene Države spremne za razgovor i da ne žele konfrontaciju sa nesvrstanima, Kisindžer je pokušao da predoči svojim domaćinima kroz predlog da na predstojećoj Konferenciji ministara inostranih poslova nesvrstanih zemalja u Limi učestvuje i on lično: „Ja se nudim kao posmatrač. Da li to prihvatate“. Zbunjen ovim predlogom, Minić je objašnjavao da to nije tako jednostavno: „Ne, ne mogu to ja prihvatiti, to treba da zajedno prihvate nesvrstane zemlje, potreban je konsensus". Nepoželjnu napetost u razgovoru i neprijatnu atmosferu koja se sve više osećala u komunikaciji dveju delegacija pokušao je da prevaziđe Kisindžer uz opasku na račun nesvrstanih: „Postali ste moćan blok na koji ćemo morati računati, tim pre što je 'disciplina' kod vas daleko bolja nego u našem bloku“. Prihvatajući Kisindžerov pomirljiv ton, Tito je uzvratio: „Malo se ta disciplina drma u poslednje vrijeme, ali mislim da ćemo to savladati, jer ne valja biti isključiv". ${ }^{29}$

Ford je, koncentrišući se na bilateralne odnose, izrazio zadovoljstvo što su se ti odnosi već dve decenije stalno „razvijali i postajali sve prošireniji“ što je bilo „korisno i za obe zemlje i za mir u celini. Kao rezultat toga,

${ }^{28}$ Isto. Tokom razdoblja koje je prethodilo Fordovoj poseti američki predsednik i Kisindžer su oštro napadali nesvrstane zemlje da su - u vreme kada blokovski antagonizmi između Istoka i Zapada slabe i kada je svet konačno ušao u fazu detanta dveju supersila formirale novi blok i dovele međunarodnu zajednicu na rub katastrofe. Jedinstven nastup nesvrstanih zemalja u OUN, višestruko povećanje cena nafte i zahteve zemalja u razvoju za uspostavljanje novog međunarodnog ekonomskog poretka, Ford i Nikson su okarakterisali kao "tiraniju većine“ i pretili su otvorenom primenom vojne sile ukoliko bi energetska situacija u svetu postala kritična za Zapad. - KPR, I-3-a/107-212. SAD i politika nesvrstavanja. Nastup Predsednika Forda na XXIX redovnom zasedanje GS UN; KPR, I-5-c/21. Sednica Saveta za nacionalnu bezbednost. Primena vojnih mera; KPR, I-5-b/104-20. Kisindžerov intervju časopisu Busines week, januar 1975. Izjava o mogućoj upotrebi vojne sile; KPR, I-5-c/25. Kisindžerov govor u Misuriju, 15. maj 1975; Fordov govor na Univerzitetu Viskonsin Instituta za svetske poslove u Milvokiju, 14. jul 1975.

${ }^{29}$ Isto. 
kod američkog naroda se razvilo osećanje ljubavi i divljenja za Vašu zemlju“. Međutim, „upravo stoga, SAD teško shvataju kad čuju kritičke primedbe $\mathrm{u}$ odnosu na američku politiku, $\mathrm{u}$ odnosu na određene akcije SAD. Ponavljam, ta ljubav, to divljenje za Jugoslaviju su u SAD veoma izraženi, pa zato i ne shvaćaju kritike koje su upućene. Zbog toga bih apelovao, a i mi ćemo se tako ponašati, za umerenost $u$ korišćenju reči i kada govorimo jedni o drugima“. Svestan da pomenute umerenosti u komunikaciji dveju strana nije bilo dovoljno i da je upravo to dodatno doprinelo pogoršanju jugoslovensko-američkih odnosa, Tito je podržao ovu Fordovu sugestiju: „Ja se po tom pitanju slažem sa Vama, jer se može neka stvar kazati vrlo prijatnim riječima iako je kritička, a može se reći nešto što može da ima drugojačiji smisao. Slažem se sa Vama i mi sada nastojimo da tako dejstvujemo. Kritika se može izraziti u prijateljskom ili neprijateljskom duhu“. Zadovoljan Titovom reakcijom, Ford je zaokružio ovu temu napomenuvši: „Obično kažem u Kongresu, to je igra reči - možemo se razilaziti, možemo ne slagati, a opet biti prijatni jedni drugima. “30

Vraćajući se na temu koja je samo ovlaš dotaknuta na početku razgovora - predstojeću Konferenciju o evropskoj bezbednosti i saradnji, čiji će domaćin biti Jugoslavija tokom 1977. godine, Kardelj je ukazao na značaj konsultacija i kontakata jugoslovenskih zvaničnika sa političarima zemalja učesnica, a posebno na saradnju sa SAD. Minić je dodao da, kada je reč o saradnji Jugoslavije i SAD, „već duže vremena između dva ministarstva i ambasada postoje tesne komunikacije, konsultacije“ i „da se to pokazalo veoma korisnim i da ih možemo dalje još više intenzivirati". Ford i Kisindžer su se složili. Kisindžer je rekao da oni „pridaju veliku pažnju razumevanju između Jugoslavije i SAD, imajući u vidu položaj Jugoslavije u nesvrstanom svetu". To je bio i jedan od razloga zbog kojih je Kisindžer istakao: „Učinićemo sve što možemo da ostanemo u bliskom kontaktu“. Pri tome, nije toliko imao u vidu pripreme za konferenciju u Beogradu koliko Sedmo vanredno zasedanje Generalne skupštine UN, posvećeno problemima ekonomskog razvoja, koje je trebalo da počne u septembru („nadam se da ćemo nastaviti da se konsultujemo i konsultovaćemo se pre naredne vanredne sednice sledećeg meseca“). ${ }^{31}$ Za SAD je bilo od velikog značaja da Jugoslavija iskoristi svoj uticaj među nesvrstanim zemljama i zemljama u razvoju i pokuša ih ubediti da odustanu od svojih radikalnih zahteva za uspostavljanje novog međunarodnog ekonomskog poretka. ${ }^{32}$

\footnotetext{
${ }^{30}$ Isto.

${ }^{31}$ Isto.
}

${ }^{32} \mathrm{U}$ američkoj administraciji preovladavao je u ovo vreme potpuno neutemeljen stav da je jugoslovensko liderstvo $u$ pokretu nesvrstanosti dovedeno $u$ pitanje izbijanjem $u$ prvi plan radikalno nastrojenih nesvrstanih zemalja (Alžira, Iraka, Sirije, Libije), koje su se 
Kisindžer je, nadovezujući se na Minićevu inicijativu u vezi sa intenziviranjem jugoslovensko-američkih kontakata, podsetio da su se njih dvojica ranije dogovorili „da budemo u kontaktu pre Specijalnog zasedanja, pošto bi mi želeli da se izbegnu konfrontacije između nesvrstanih i razvijenih zemalja. Želja nam je da Specijalno zasedanje bude stvarno konstruktivno zasedanje". ${ }^{33}$

$\mathrm{Na}$ kraju ove runde razgovora, predsednik Ford je pokušao da otkloni još jednu zabludu koja je inače bila prisutna $u$ jugoslovenskim političkim krugovima, u pogledu njegovog negativnog odnosa prema Kisindžeru i pojedinim ključnim ličnostima iz američke administracije postavljenim svojevremeno od strane predsednika Niksona. Razdoblje koje je prethodilo Fordovoj poseti Jugoslaviji proteklo je u znaku oštre polemike $u$ Kongresu u vezi sa Kisindžerovom neuspelom posredničkom misijom na Bliskom istoku, čiji je rezultat bio ne samo pogoršanje odnosa sa arapskim zemljama nego i sa Izraelom, koji je vrlo burno reagovao zbog Kisindžerovog pritiska da se odustane od ekstremističke politike prema Arapima i potpunog kraha američke politike u Indokini (poraz sva tri režima sa tog prostora, koji su uživali ogromnu vojnu i političku podršku SAD i Kisindžera - poraz Tijeevog režima u Južnom Vijetnamu; poraz Lon Nolovog režima u Kambodži i na kraju, poraz desničarske vlade u Laosu i povlačenje američke misije iz te zemlje). ${ }^{34}$ Jugoslovenska štampa i jugoslovenski političari pažljivo su pratili polemike i rasprave koje su se odvijale u Kongresu, ali i u samom Stejt departmentu, koje su ukazivale na odsustvo harmonije unutar američkog političkog vrha. U tom kontekstu, aktuelizovala se dilema da li Kisindžer uopšte i dalje uživa poverenje predsednika Forda i koliko je okončanje diplomatske misije ranijeg američkog ambasadora Malkolma Tuna, a dolazak u Jugoslaviju novog ambasadora Lorensa Silbermana, deo kadrovske reorganizacije i Fordovog

nametnule kao autentični predstavnici Trećeg sveta i „trećeg bloka“ u beskompromisnoj borbi za prava siromašnog Juga antagoniziranog prema bogatom Severu. U tom duhu, zvaničnici iz Vašingtona su smatrali da novi prioriteti pokreta nesvrstanih, usmereni na radikalnu transformaciju postojećeg sistema međunarodnih odnosa, neminovno vode marginalizaciji Titove uloge u toj asocijaciji, a favorizovanju alžirskog predsednika Bumedijena koji je, kao domaćin samita nesvrstanih na kome je pokrenut projekat novog međunarodnog ekonomskog poretka, izbio naglo u vrh. - AJ, KPR, I-5-c/23. Neke američke ocene politike nesvrstanih zemalja; isto, I-5-c/14. Samit u Alžiru.

${ }_{33}$ AJ, KPR, I-3-1/107-215. Stenografske beleške sa razgovora Predsednika Republike Josipa Broza Tita sa Predsednikom SAD, Njegovom ekselencijom gospodinom Geraldom R. Fordom, održanih 3. avgusta 1975. u Beogradu; FRUS, 1969-1976, Volume E-15, Part 1, Documents on Eastern Europe, 1973-1976, Yugoslavia, doc 73. Memorandum of Conversation, Belgrade, August 3, 1975

${ }^{34}$ Godišnjak Instituta za međunarodnu politiku i privredu, 1975, Beograd 1976, 7-19, 21-23, 399-405. 
nezadovoljstva učinkom administracije njegovog prethodnika, Ričarda Niksona. ${ }^{35}$

Svestan da pomenute spekulacije u jugoslovenskim političkim krugovima mogu negativno uticati na poziciju američkih diplomata u sklopu njihove komunikacije sa Titom i njegovim saradnicima, Ford je na kraju razgovora pomalo napadno i neočekivano naglasio: „Imam vrlo blizak i srdačan odnos sa sekretarom Kisindžerom. Među nama nema razlika. A ambasadora sam ja postavio. On ima moje puno poverenje, tako da imamo dobru situaciju.... ${ }^{36}$ Tokom naredne runde razgovora, Tito je najavio da će i njegova vlada akreditovati novog ambasadora u SAD. Umesto ambasadora Tome Granfila, u Vašington iduće godine dolazi Dimče Belovski.

Pošto je vreme za prvu rundu razgovora dveju delegacija isteklo, $u$ zgradi SIV-a priređena je svečana večera za visoke goste iz SAD, tokom koje su Tito i Ford održali uobičajene zdravice. Tito je napomenuo da u Fordovoj poseti vidi „novu potvrdu tradicionalnog prijateljstva između naših naroda... provjereno i učvršćeno kroz savezništvo u dva svjetska rata“, a zasnovano na „dugoročnoj, obostranoj zainteresovanosti za stalno unapređenje saradnje“. „Principi na kojima se ta saradnja zasniva, a koji su potvrđeni i prilikom moje posjete Vašoj zemlji, pokazali su veliku vitalnost, što se izražava, kako u pomenutim rezultatima, tako i u prevazilaženju raznih teškoća u međusobnim odnosima“. ${ }^{37}$

Odgovarajući na Titovu zdravicu Ford je, moglo bi se reći, bio mnogo izdašniji od svog domaćina kada su u pitanju lični komplimenti i iskazivanje poštovanja prema spoljnopolitičkom kursu države na čijem je čelu. „Mi Amerikanci oduvek smo cenili naše prijateljske veze s Jugoslavijom. Amerikanci se naročito dive jugoslovenskom duhu za nezavisnost. Kadgod je negde nezavisnost ugrožena, narodi se svugde ugledaju na primer borbe jugoslovenskih naroda kroz njihovu istoriju. Iz tih primera oni su crpili inspiraciju i snagu. Gospodine Predsedniče taj duh i Vaša rukovodeća hrabrost doveli su uspešno jugoslovenske narode, kroz teškoće drugog svetskog rata, u eru mira, stabilnosti i ekonomskog napretka“. U istom duhu Ford je završio svoj govor karakterišući Tita kao ličnost „čija hrabrost,

${ }^{35}$ AJ, KPR, I-5-b/104-20. Položaj Kisindžera u američkom vrhu; AJ, KPR, I-5-c/23. Depeša iz ambasade u Vašingtonu, br. 429, 26. mart 1975. Neuspeh Kisindžerove turneje; isto. Depeša iz ambasade u Vašingtonu, br. 451, 28. mart 1975; AJ, KPR, I-5-b/104-20. Krupne promene u američkoj administraciji; AJ, KPR, I-5-b/104-20. Ocena američke spoljne politike.

${ }^{36}$ AJ, KPR, I-3-1/107-215. Stenografske beleške sa razgovora Predsednika Republike Josipa Broza Tita sa Predsednikom SAD, Njegovom ekselencijom gospodinom Geraldom R. Fordom, održanih 3. avgusta 1975. u Beogradu; FRUS, 1969-1976, Volume E-15, Part 1, Documents on Eastern Europe, 1973-1976, Yugoslavia, doc 73. Memorandum of Conversation, Belgrade, August 3, 1975.

${ }^{37}$ Zdravica na svečanoj večeri, Borba, 4. avgust 1975. 
mudrost i vođstvo toliko mnogo znače za Jugoslaviju i za svet u kojem njegova zemlja igra tako važnu ulogu“. ${ }^{38}$

Istovremeno, američki predsednik je još jednom istakao američki interes za očuvanje nezavisne i nesvrstane Jugoslavije: „Jugoslavija zauzima istaknutu ulogu u međunarodnim odnosima pod Vašim rukovodstvom, gospodine Predsedniče. Sjedinjene Države priznaju da politika nesvrstavanja Vaše zemlje predstavlja aktivan doprinos većem razumevanju među narodima. Jugoslavija i Sjedinjene Države su neprekidno radile na saradnji koja se zasniva na ravnopravnosti svih članova međunarodne zajednice na osnovu Povelje Ujedinjenih nacija“. Ono što je međutim posebno privuklo pažnju diplomata koje su prisustvovale svečanoj večeri u zgradi SIV, bio je deo Fordove zdravice u kojoj je on otvoreno izrazio svoje nezadovoljstvo nastupom nesvrstanih zemalja u Generalnoj skupštini $u$ sklopu njihovih nastojanja da se radikalno transformiše postojeći sistem međunarodnih odnosa. „Bili smo uznemireni neodgovornošću (misli na nesvrstane zemlje - D. B.) koja se odrazila u nekim diskusijama o životnim ekonomskim problemima u forumu Ujedinjenih nacija. Sve veće udaljavanje između razvijenih zemalja i zemalja u razvoju može samo da povredi najbolje interese obe strane i da dovede u opasnost izglede za rešavanje svetskih problema". ${ }^{39}$

Tokom druge runde razgovora vođenih narednog dana, posle svečanog doručka u zgradi SIV-a, ključna tema bila je kriza na Bliskom istoku. Koliko se ta tema stalno prožimala i preplitala sa gotovo svim važnijim zbivanjima u međunarodnim odnosima, moglo se videti i iz pomalo dramatičnog početka jugoslovensko-američkih razgovora, 4. avgusta, uslovljenog zabrinjavajućom informacijom koju je upravo $\mathrm{u}$ tom momentu primio Kisindžer, a potom i saopštio Titu i njegovim saradnicima. Radilo se o napadu na američki konzulat u Maleziji od strane japanske Crvene armije, koju je Kisindžer povezivao sa palestinskim organizacijama („ti Japanci su isti oni koji su odgovorni za ubistva u Tel Avivu“). Skrećući pažnju na ovu „šokantnu situaciju“, predsednik Ford je ukazao na evidentan uticaj međunarodnog terorizma na krizu na Bliskom istoku. ${ }^{40}$

Time je, već na samom početku razgovora, Ford donekle pojasnio i pokušao da opravda logiku američke strategije rešavanja bliskoistočne krize

${ }^{38}$ Isto.

${ }^{39}$ Isto; Department of State Bulletin, September 8, 1975, p. 372.

${ }^{40}$ AJ, KPR, I-3-1/107-215. Stenografske beleške sa razgovora Predsednika Republike Josipa Broza Tita sa Predsednikom SAD, Njegovom ekselencijom gospodinom Geraldom R. Fordom, održanih 4. avgusta 1975. u Beogradu; Mile Bjelajac i Marija Obradović, Prilog za istoriju odnosa SFRJ i SAD. Američki zapisnik sa razgovora Tito-Ford, održanih 4. avgusta 1975. u Beogradu, Jugoslavija, Tokovi istorije, 3-4/2003, 133-147; FRUS, 1969-1976, Volume E-15, Part 1, Documents on Eastern Europe, 1973-1976,_Yugoslavia, doc 74. Memorandum of Conversation, Belgrade, August 4, 1975. 
„korak po korak“, u kojoj je očigledno tek poslednji „korak“ trebalo da bude učinjen u cilju zaštite prava palestinskog naroda. Ta strategija, koja je davala ton Kisindžerovoj posredničkoj misiji na Bliskom istoku tokom prve polovine 1975. godine, kao što je napomenuto, doživela je potpun neuspeh i postala je predmet ozbiljnog preispitivanja u američkom Kongresu i Stejt departmentu. ${ }^{41}$ Ukoliko se u skoroj budućnosti ne otkloni zastoj u pregovorima oko rešavanja krize na Bliskom istoku - po mišljenju Forda i Kisindžera - neizbežno će doći do novog i još krvavijeg rata na tom prostoru, koji se lako može proširiti i na direktan sukob između SAD i SSSR. Zbog toga je američka strana smatrala predstojeće Kisindžerove pregovore na Bliskom istoku značajnim. Budući da je Titov imao veliki uticaj na arapske nesvrstane zemlje, a Sjedinjene Države već deset godina nisu imale kontakte sa arapskim svetom, Ford je pozvao Tita da preuzme ulogu posrednika između Arapa i Amerikanaca i ubedi arapske lidere da zauzmu „umereniji kurs“ po pitanju razrešenja krize. Poseban značaj u tom kontekstu mogao je imati "konstruktivan“ jugoslovenski nastup na predstojećoj Ministarskoj konferenciji nesvrstanih zemalja u Limi (Peruu), koja treba da se održi od 25. do 30. avgusta 1975, neposredno uoči realizacije nove Kisindžerove posredničke misije na Bliskom istoku. ${ }^{42}$

Pošto je predsednik Ford naglasio da se njegova vlada zalaže za rešavanje bliskoistočne krize punom primenom rezolucija Ujedinjenih nacija 242 i $338,{ }^{43}$ Tito mu je skrenuo pažnju da najveći problem leži upravo u tome što Izrael ne poštuje te rezolucije i da stoga svaki napredak u razrešenju krize na Bliskom istoku zavisi od Izraela - „Izrael nije postupio u skladu sa UN rezolucijama koje ste pomenuli... Mi mislimo da Izraelu ne treba dozvoliti da radi što želi... Izrael nastavlja da krši volju drugih i zato misli-

${ }^{41}$ AJ, KPR, I-5-b/104-20. Položaj Kisindžera u američkom vrhu; AJ, KPR, I-5-c/23. Depeša iz ambasade u Vašingtonu, br. 429, 26. mart 1975. Neuspeh Kisindžerove turneje; isto. Depeša iz ambasade u Vašingtonu, br. 451, 28. mart 1975; AJ, KPR, I-5-b/104-20. Krupne promene u američkoj administraciji; AJ, KPR, I-5-b/104-20. Ocena američke spoljne politike.

${ }^{42}$ AJ, KPR, I-3-1/107-215. Stenografske beleške sa razgovora Predsednika Republike Josipa Broza Tita sa Predsednikom SAD, Njegovom ekselencijom gospodinom Geraldom R. Fordom, održanih 4. avgusta 1975. u Beogradu; Mile Bjelajac i Marija Obradović, Prilog za istoriju odnosa SFRJ i SAD. Američki zapisnik sa razgovora Tito-Ford, održanih 4. avgusta 1975. godine u Beogradu, Jugoslavija, Tokovi istorije, 3-4/2003, 133-147; FRUS, 1969-1976, Volume E15, Part 1, Documents on Eastern Europe, 1973-1976, Yugoslavia, doc 74. Memorandum of Conversation, Belgrade, August 4, 1975.

${ }^{43}$ Rezoluciju 242, po okončanju trećeg arapsko-izraelskog rata (od 6. do 10. juna 1967), usvojio je Savet bezbednosti UN 22. novembra 1967. U njoj se zahteva hitno povlačenje izraelskih snaga sa okupiranih teritorija, obustava ratnog stanja i priznanje suvereniteta, teritorijalnog integriteta i političke nezavisnosti svih država ovog područja. Rezoluciju 338 usvojio je, posle okončanja četvrtog arapsko-izraelskog rata (od 6. do 26. oktobra 1973), Savet bezbednosti 26. oktobra 1973 . Ona se svodi na poziv za okončanje rata i na primenu Rezolucije 242. 
mo da treba izvršiti pritisak na Izrael“. Zbog takvog izraelskog ponašanja neke arapske zemlje su pokrenule inicijativu da se na narednom zasedanju Generalne skupštine UN, Izrael izbaci iz te organizacije. „To bi bio veoma nesrećan razvoj za UN. To bi bilo loše za UN i to bi dovelo do podele $u$ nesvrstanom svetu“. O tome će se raspravljati u Limi, što će jako iskomplikovati poziciju ministra Minića na toj konferenciji. Tito je precizirao da je Jugoslavija „protiv izbacivanja Izraela iz UN. To bi bila veoma nesrećna situacija. Imam veliko poverenje da ekstremne mere neće biti primenjene. Ali postoje i druge, srednje mere. Mi nismo protiv sankcija. Trebalo bi da pokušate da ubedite Izrael, jer u ovom slučaju oni su vrlo kratkovidi“. Jedini način da se razreši kriza na Bliskom istoku, po Titu, svodio se na povlačenje Izraela sa svih okupiranih teritorija i priznanje suvereniteta i nacionalne nezavisnosti svih država sa tog prostora (tu je imao u vidu kako priznanje suvereniteta Izraela od strane arapskih zemalja, tako i izraelsko priznanje nezavisne palestinske države) ${ }^{44}$

Ford se saglasio sa Titom da treba izvršiti određen pritisak na Izrael i naterati ga da zauzme kooperativniji stav u pogledu sveobuhvatnog rešenja bliskoistočne krize. „Proveli smo maksimalno vreme pokušavajući da ubedimo arapske lidere da moraju da povuku neke poteze, a sada ćemo to da radimo sa Izraelom". Veliku prepreku na tom putu, međutim, Ford je video $\mathrm{u}$ radikalizmu pojedinih arapskih zemalja i njihovom nastojanju da izbace Izrael iz UN. „Ako Izrael bude suspendovan, sva će podrška Izraelu ići preko Sjedinjenih Američkih Država i Izraelci će doći kod nas i pitati kako se možemo osloniti na nagodbu sa policijskim snagama UN, kada mi čak nismo ni u Ujedinjenim nacijama... Sve što bi se tako učinilo, bilo bi da Izrael ispadne mučenik i otežalo bi napredak ka rešenju... Kada se radi o Izraelu, njihova strategija je da im daleko više odgovaraju radikalni arapski lideri, nego umereni. Ukoliko su Arapi antiamerički ili antisovjetski nastrojeni, Izraelci mogu da apeluju na grupe u SAD koje su antisovjetske i da stoga imaju mnogo bolje šanse da njihovi stavovi budu prihvaćeni“. Ford je naglasio da bi arapski zahtev za isključenje Izraela iz UN primorao Sjedinjene Države da uvedu embargo na uvoz nafte iz arapskog sveta, što bi nesumnjivo teško pogodilo nerazvijene zemlje, a takođe i usporilo oporavak američke privrede i time onemogućilo SAD da pruža pomoć nerazvijenima. Stoga se obratio Titu: „Važno je za Vas gospodine Predsedniče da utičete na Arape na umerenom kursu. To je $\mathrm{u}$ njihovom interesu da nastave politiku

${ }^{44}$ AJ, KPR, I-3-1/107-215. Stenografske beleške sa razgovora Predsednika Republike Josipa Broza Tita sa Predsednikom SAD, Njegovom ekselencijom gospodinom Geraldom R. Fordom, održanih 4. avgusta 1975. u Beogradu; FRUS, 1969-1976, Volume E-15, Part 1, Documents on Eastern Europe, 1973-1976, Yugoslavia, doc 74. Memorandum of Conversation, Belgrade, August 4, 1975. 
umerenosti koju su vodili. Ovo je već imalo pozitivan uticaj na američku politiku koja je sada u potpunosti angažovana na ravnomeran način“ ". ${ }^{45}$

Bilo je očigledno da jugoslovenska strana nije naročito impresionirana izjavama o američkoj nepristrasnosti u odnosu na sukobljene strane na Bliskom istoku. Nespremnost Izraela da se povuče sa okupiranih arapskih teritorija u velikoj meri uslovljena je upravo američkim tolerisanjem izraelske isključivosti po tom pitanju. U jugoslovenskim političkim krugovima procenjivano je da je takva politika SAD dovela do ćorsokaka u pregovorima i ohrabrila Izraelce da ignorišu rezolucije UN o Bliskom istoku. Stoga je Tito tokom razgovora sa Fordom uporno insistirao na tome da Amerikanci pojačaju pritisak na Izrael da odustane od svojih maksimalističkih zahteva i ne zloupotrebljava američku podršku. Upravo stoga, Jugosloveni su glavni uzrok zastoja u rešavanju bliskoistočne krize videli u slabosti američke politike etapnog rešavanja te krize kroz strategiju "korak po korak“. „Nadali smo se da će se neki rezultati postići sa korak po korak pregovorima - oni se sprovode od strane sekretara Kisindžera. Ali, samo je jedan korak postignut. Sada mi se čini da smo u pat poziciji... Svestan sam da ne možete da uradite ove stvari preko noći, ali svaki korak ne bi trebao da traje deset godina“. Minić je bio još direktniji i postavio je pitanje: „Šta mislite, gospodine predsedniče i sekretare, da će se desiti ako ne bude uspeha? Pomenuli ste rat, ali koje druge ideje osim svojih napora imate?". Ford je, pomalo nevoljno, priznao da bi u tom slučaju Amerikanci morali da nastave sa preispitivanjem takve politike i prihvate opciju (na kojoj je, inače, insistirala Jugoslavija), da se pristupi celovitom rešenju bliskoistočne krize, $u$ sklopu jedne međunarodne konferencije, uz učešće SSSR-a i svih involviranih arapskih zemalja i predstavnika palestinskog naroda. „Jedna mogućnost je da ćemo preći u Ženevu i zagovarati širok sporazum, iako znamo da je to manje poželjan tok akcije“. Objašnjavajući razloge zbog kojih se SAD protive održavanju Ženevske konferencije, Kisindžer je napomenuo da bi u tom slučaju „Arapi tražili da se tu uključi Palestinska oslobodilačka organizacija, a to bi moglo da dovede do zastoja koji bi mogao da traje mesecima“, jer Izraelci odlučno odbijaju da sednu za pregovarački sto sa Palestincima. Ford i Kisindžer su smatrali da se palestinsko pitanje može rešiti tek pošto se prethodno postignu posebni sporazumi sa Egiptom i Sirijom. Dodatni argument $u$ prilog američke teze o nepoželjnosti održavanja Ženevske konferencije u skoroj budućnosti, svodio se na stav o nejedinstvu Arapa o pitanju konkretnog rešenja krize na Bliskom istoku: „Oni koji poznaju Arape, smatraju da sa četiri grupe njih u istoj sobi, razgovori ne bi baš protekli mirno. To bi išlo na ruke izraelskoj strategiji odlaganja“". ${ }^{46}$

\footnotetext{
${ }^{45}$ Isto.

${ }^{46}$ Isto.
} 
Objašnjavajući svojim sagovornicima komplikacije koje bi imao u Kongresu u slučaju da se rešenje bliskoistočne krize u sadašnjem momentu traži na Ženevskoj konferenciji, ${ }^{47}$ Ford je sugerisao Titu da iskoristi predstojeću posetu delegacije američkog Kongresa da ih informiše o jugoslovenskim stavovima o Bliskom istoku. „Oni ispoljavaju veliko poštovanje prema Vama i Jugoslaviji. Mislim da bi bilo korisno da vodite iskrenu diskusiju sa njima i izložite im svoju analizu situacije na Bliskom istoku. To bilo veoma korisno za nas". Pri tome je Titu indirektno skrenuta pažnja da upravo Kongres donekle predstavlja ograničavajuću instancu u vojnoj saradnji Jugoslavije i SAD i pruža otpor rešavanju pitanja prodaje oružja Jugoslaviji. „Shvatam da možda postoje neki ljudi u birokratiji koji ne pridaju odgovarajuću pažnju i ne doprinose ubrzanju realizacije zahteva da se to uradi [da se udovolji jugoslovenskim zahtevima $u$ vezi sa isporukom vojne opreme D. B.], ali kada se vratim ja ću tom lično posvetiti svoju pažnju i mogu da Vas uverim da će ta stvar biti rešena". ${ }^{48}$

Drugo pitanje koje je bilo od posebnog značaja za bilateralnu saradnju, a koje je takođe samo ovlaš dotaknuto, ticalo se američke ekonomske podrške privrednom razvoju Jugoslavije i investiranju američkog kapitala u jugoslovensku industriju. Kardelj je skrenuo pažnju svojim gostima da Jugoslavija ima veliku potrebu za stranim kapitalom. „Mi verujemo da najveći izvor kapitala dolazi iz Sjedinjenih Država. Želimo da imamo veći upliv američkog kapitala u našu industriju. U industriji, poljoprivredi, tehnologiji, know-how, mi smo želeli da dobijemo više od Sjedinjenih Država. Iako se naši sistemi razlikuju, mi imamo sistem koji nam omogućava da koristimo i javne i privatne investicije za izgradnju naše zemlje. Pripremamo novi zakon o investicijama, koji će olakšati situaciju investitorima iz inostranstva. ${ }^{49}$ Ali, mi smo primetili da još uvek postoji nepoverenje u nekim ame-

${ }^{47}$ Ford i Kisindžer su uoči posete Jugoslaviji imali sastanak sa najuticajnijim kongresmenima u vezi sa zastojem u pregovorima o rešavanju bliskoistočne krize. Tom prilikom kongresmeni su izrekli ozbiljne primedbe na politiku američke administracije koja je dovela do opšteg opadanja prestiža SAD na međunarodnoj sceni. Oni su insistirali na preispitivanju politike „korak po korak“ i nagovestili mogućnost svog energičnijeg angažovanja i uplitanja u sklopu spoljnopolitičkih akcija predsednika i državnog sekretara SAD. - AJ, KPR, I-5-c/23.

${ }^{48}$ AJ, KPR, I-3-1/107-215. Stenografske beleške sa razgovora Predsednika Republike Josipa Broza Tita sa Predsednikom SAD, Njegovom ekselencijom gospodinom Geraldom R. Fordom, održanih 4. avgusta 1975. u Beogradu; FRUS, 1969-1976, Volume E-15, Part 1, Documents on Eastern Europe, 1973-1976, Yugoslavia, doc 74. Memorandum of Conversation, Belgrade, August 4, 1975.

${ }^{49}$ Jugoslavija je bila prva socijalistička zemlja koja je obezbedila pravne okvire za investicije stranog kapitala u svoju privredu. Prvi u seriji zakona koji su regulisali ovu oblast donet je još 1967. godine. Neizvesnost u pogledu transfera dobiti, pravna nesigurnost i bojazan da bi novi propisi mogli dovesti u pitanje strana ulaganja, odvraćali su potencijalne strane investitore od zaključivanja poslova u Jugoslaviji. Stoga su 1971. doneti novi zakonski i ustavni amandmani, po kojima prava koja bi strani investitor stekao ugovorom o zajednič- 
ričkim krugovima. Bilo bi dobro da administracija SAD više pomogne da se stvori atmosfera u kojoj bi se razvilo poverenje u ovoj saradnji“. ${ }^{50}$

$\mathrm{S}$ američke strane je ispoljeno razumevanje u pogledu jugoslovenskih zahteva za proširivanje obima američkih investicija za razvojne programe u Jugoslaviji. Ford je zadovoljno napomenuo da je impresioniran onim što je video u Jugoslaviji i da je očigledno „da su američka industrija i kapital veoma dobro primljeni u Jugoslaviji i da su tu postignuti veliki uspesi“. Ukazao je, međutim, i na negativan uticaj aktuelne energetske krize na sposobnost američke privrede i investitora da prošire saradnju sa jugoslovenskim privrednicima. Ta investiciona sposobnost uslovljena je kapacitetom i snagom američke privrede, koja je zbog naftnog embarga zapala u ozbiljnu recesiju. „Mi želimo da proširimo naše odnose u celom svetu i da bi to uradili moramo da imamo zdravu privredu". Međutim, konfrontacija nesvrstanih zemalja sa razvijenim zemljama, po Fordu, ozbiljno onemogućava ovakva nastojanja njegove vlade. Ova konstatacija otvorila je nove teme razgovora, oko kojih je postojala značajna kolizija u stavovima Jugoslavije i SAD. Radilo se o nizu međusobno povezanih pitanja iz sfere međunarodne ekonomske problematike: pitanje uspostavljanja novog međunarodnog ekonomskog poretka, položaja nerazvijenih zemalja na svetskom tržištu, priprema za Sedmo specijalno zasedanje Generalne skupštine UN posvećenog problemima ekonomskog razvoja i konfrontacije Sever-Jug. ${ }^{51}$

Što se tiče ovog zasedanja, Miloš Minić je istakao da će njegovi rezultati u velikoj meri zavisiti od spremnosti razvijenih zemalja da izađu u susret zahtevima zemalja u razvoju i nesvrstanim zemljama. U tom kontekstu naglasio je „da će tu Sjedinjene Države igrati ključnu ulogu“ i da će „ishod zavisiti u velikoj meri od pozicije Sjedinjenih Država“. Upozorio je sagovornike iz Vašingtona da se katastrofalno ekonomsko stanje u nerazvijenim afro-azijskim zemljama tiče celog sveta i da bi tokom oštrih debata, koje će se o tome voditi u Generalnoj skupštini UN, SAD trebalo da iskažu više strpljenja, a ne da se drže rezervisano, kao što je to bio slučaj tokom

kom ulaganju nisu mogla da budu umanjena kasnije donetim zakonima i propisima. Premda se broj stranih investitora u Jugoslaviji povećao, jugoslovenski ekonomisti nisu bili zadovoljni ukupnim bilansom reformskog kursa i normativnim rešenjima, tako da se uporedo se izradom Zakona o udruženom radu pripremao i novi zakon koji bi doprineo aktivnijem uključivanju stranih investitora. - Ljubiša S. Adamović, Džon R. Lempi, Rasel O. Priket, Američko-jugoslovenski ekonomski odnosi posle Drugog svetskog rata, Beograd 1990, 112$116,134-141$.

${ }^{50}$ AJ, KPR, I-3-1/107-215. Stenografske beleške sa razgovora Predsednika Republike Josipa Broza Tita sa Predsednikom SAD, Njegovom ekselencijom gospodinom Geraldom R. Fordom, održanih 4. avgusta 1975. u Beogradu; FRUS, 1969-1976, Volume E-15, Part 1, Documents on Eastern Europe, 1973-1976, Yugoslavia, doc 74. Memorandum of Conversation, Belgrade, August 4, 1975.

${ }^{51}$ Isto. 
prethodnog, Šestog specijalnog zasedanja svetskog parlamenta. Predsednik Ford se nije složio sa ovim Minićevim primedbama. Napomenuo je da su SAD permanentno imale „konstruktivan stav" o pitanju saradnje sa zemljama u razvoju, da je politika njegove administracije oduvek bila da pomaže nerazvijenima i da će takav stav ta administracija zadržati i na narednom zasedanju Generalne skupštine. „Sadašnja kriza nije naša krivica. To je zbog ekstremnog povećanja cena nafte. Mi želimo da radimo da izbegnemo katastrofu... Mi smo posvećeni UN. Mi smo ostavili mnogo novca i vremena u toj organizaciji. Ali, ona ne može biti organizovana i kontrolisana od strane blokova“. ${ }^{52}$ Kisindžer se nadovezao na poznate optužbe da odgovornost za tešku ekonomsku krizu u svetu snose zemlje izvoznice nafte, ukazujući na to da se zapravo radi o „ideološkoj konfrontaciji“, o filozofskim raspravama lišenim konkretnog sadržaja i pokušaju da se uspostavi potpuno nov međunarodni ekonomski poredak upravljen direktno protiv interesa zapadnih sila. ${ }^{53}$ Međutim, na zadovoljstvo Tita i njegovih sagovornika, s američke strane date su garancije da će SAD zauzeti konstruktivan stav u pogledu konkretnih predloga o energiji, sirovinama, finansiranju i pitanja razvoja radi ublažavanja sve većeg jaza između razvijenog Severa i siromašnog Juga. „Takođe ćemo podržati dijalog potrošači-proizvođači i osećamo da, dok sednica Ujedinjenih nacija može raspravljati o pitanjima politike, možemo da pređemo na konkretne pregovore u tri ili četiri komisije uspostavljene u okviru Energetske konferencije“. ${ }^{54}$

Pošto su razgovori završeni u 11.30 časova (prema ranije utvrđenom programu), u Sali federacije u zgradi SIV-a, dvojica predsednika su održali konferenciju za štampu, a potom u zdravici tokom „radnog ručka“ još jednom izložili svoje stavove o razmatranim međunarodnim pitanjima.

Američki predsednik je, i na konferenciji za štampu i u svojoj zdravici, podvukao odlučnost svoje vlade da doprinese ostvarenju najvažnijeg cilja SAD - a to je "svet u kome će svi narodi uživati mir, prosperitet i bezbednost". Iskoristio je priliku da još jednom optuži pojedine nesvrstane

${ }^{52}$ Ford je, pri tome, mislio na „Treći blok“ - blok nesvrstanih zemalja koje su jedinstveno nastupale u Ujedinjenim nacijama, zalažući se za radikalnu transformaciju postojećeg sistema međunarodnih ekonomskih odnosa koji je po, njima, bio skrojen po meri zapadnih sila.

${ }^{53}$ Pri tome Ford je potpuno ignorisao činjenicu da su na Šestom specijalnom zasedanju Generalne skupštine UN usvojeni Deklaracija o uspostavljanju novog međunarodnog ekonomskog poretka i poseban Program akcije kojim su konkretizovane mere u cilju sprovođenja ovog projekta.

${ }_{54}$ AJ, KPR, I-3-1/107-215. Stenografske beleške sa razgovora Predsednika Republike Josipa Broza Tita sa Predsednikom SAD, Njegovom ekselencijom gospodinom Geraldom R. Fordom, održanih 4. avgusta 1975. u Beogradu; FRUS, 1969-1976, Volume E-15, Part 1, Documents on Eastern Europe, 1973-1976, Yugoslavia, doc 74. Memorandum of Conversation, Belgrade, August 4, 1975. 
arapske zemlje da zbog svoje ekstremističke politike snose krivicu za neuspeh pregovora o razrešenju krize na Bliskom istoku i za aktuelnu svetsku ekonomsku krizu i pozvao ih da zauzmu elastičnije stavove: „Smatram da je sadašnji ćorsokak neodrživ. Smatram, takođe, da je potrebna umerenost na svim stranama, kao i fleksibilnost, ukoliko želimo da izbegnemo posledice koje bi mogle da budu vrlo teške. Ponavljam, znači, umerenost i fleksibilnost su neophodni da bi se postigli željeni rezultati“. Pohvalio je doprinos Jugoslavije u ostvarivanju pomenutih ciljeva kojima streme Sjedinjene Države i posebno istakao svoje zadovoljstvo razgovorima sa Titom. „Naročito cenim to što mi se ukazala mogućnost da čujem Vaše mišljenje o bilateralnim pitanjima i o problemima koji se odnose na međunarodnu zajednicu. Cenim Vaše iskustvo i Vašu mudrost koji su došli do izražaja prilikom našeg razgovora i razmatranja svih pitanja“. ${ }^{55}$

Tito je u svojoj zdravici takođe izrazio zadovoljstvo tonom i sadržajem razgovora, povezujući ih sa konstruktivnim tokom nedavno održane Konferencije o bezbednosti i saradnji, konstatujući da su razgovori sa predsednikom Fordom upravo bili „u duhu Deklaracije koju smo usvojili u Helsinkiju“. Napomenuo je da se Jugoslavija dosledno pridržava načela politike nesvrstanosti i da će to činiti i u budućnosti. U sklopu takve politike je izuzetno važno da se dalje unapređuje saradnja sa SAD, „da se učvršćuje međusobno povjerenje i izgrađuju takvi međunarodni odnosi u kojima će nezavisnost, ravnopravnost i saradnja svih naroda dolaziti do sve većeg izražaja“. Naglašavajući da su mu razgovori sa Fordom „pričinili veliko zadovoljstvo“, izrazio je nadu da će ubrzo ukazati prilika da njegov gost ponovo poseti Jugoslaviju i ostane malo duže, kako bi se bolje upoznao sa narodima Jugoslavije koji „gaje prijateljstvo prema američkom narodu i žele da se te veze produbljuju i učvršćuju“. ${ }^{56}$

S obzirom na učestale izjave američkih zvaničnika u kojima se osuđuje formiranje bloka nesvrstanih zemalja, ali i sve brojnije optužbe na račun politike nesvrstanosti generalno, za Jugoslaviju je bilo izuzetno značajno to što je u zajedničkom jugoslovensko-američkom saopštenju povodom razgovora Tito-Ford ponovo potvrđen „trajni interes Sjedinjenih Američkih Država i njihova podrška nezavisnosti, integritetu i nesvrstanoj poziciji Jugoslavije". U tom smislu zajednički kominike predstavlja reafirmaciju principa bilateralne saradnje, koje su u formi posebne platforme (Vašingtonske deklaracije) usvojili Tito i Nikson 1971. godine i koji su činili osnovu saradnje dveju država tokom prve polovine 70 -ih godina. Radi se o principu nezavisnosti i poštovanja suvereniteta i teritorijalnog integriteta, principu mirnog rešavanja sporova, uzajamnog uvažavanja i pune ravnopravnosti

\footnotetext{
${ }^{55}$ Borba, 5. avgust 1975.

${ }^{56}$ Isto.
} 
bez obzira na razlike $u$ društveno-političkim sistemima. Na samom kraju saopštenja podvučeno je: „Principi izloženi u ovoj Zajedničkoj izjavi su osnova odnosa Jugoslavije i Sjedinjenih Američkih Država. Oni predstavljaju čvrstu bazu na kojoj će se prijateljski odnosi dve zemlje ubuduće razvijati“. U zajedničkom saopštenju je takođe potvrđeno stanovište na kome je Jugoslavija uporno insistirala, „da je međuzavisnost svih naroda i zemalja, kako razvijenih tako i zemalja u razvoju, jedan od bitnih faktora u pronalaženju pravednih rešenja za efikasan ekonomski razvoj“. U vezi sa gorućim problemom - otklanjanjem opasnog jaza u razvoju između Severa i Juga, potvrđena je odlučnost dvaju predsednika da obojica učine sve što je u njihovoj moći radi „iznalaženja pravednih rešenja na bazi poboljšanja međunarodne saradnje i poštovanja interesa svih". ${ }^{57}$

Sudeći po tekstu zajedničkog saopštenja i izjavama dvojice predsednika posle sastanka u Beogradu, čini se da su obe strane bile zadovoljne ishodom razgovora. Tito je direktan kontakt sa Fordom iskoristio da pojasni Amerikancima poziciju Jugoslavije u pokretu nesvrstanosti i ubedi ih da je jugoslovenska spoljna politika i dalje komplementarna sa globalnim interesima SAD. Zahvaljujući tome, omekšao je stav Forda u pogledu veće američke podrške jugoslovenskim zahtevima za vojne nabavke i privatne američke investicije za jugoslovenske razvojne projekte. I ono što je najvažnije, obezbedio je uslove za opšte poboljšanje bilateralnih odnosa i prisniju političku saradnju dve zemlje, koja je poslednjih godina ozbiljno dovedena $\mathrm{u}$ pitanje. S druge strane, kada je reč o Sjedinjenim Državama, može se reći da se predsednik Ford iz prve ruke uverio da će Jugoslavija voditi računa o interesima SAD na predstojećem Ministarskom sastanku nesvrstanih zemalja u Limi, koji je trebalo da se održi neposredno uoči realizacije nove Kisindžerove posredničke misije na Bliskom istoku. Titova spremnost da posreduje između SAD i nesvrstanih zemalja oko bliskoistočne krize i oko otklanjanja nesuglasica u sklopu sve oštrije konfrontacije Sever-Jug, predstavljala je važne elemente zbog kojih je američki predsednik mogao pozitivno oceniti bilans svojih razgovora sa jugoslovenskim zvaničnicima. Pored toga, kroz lični kontakt sa Titom i otvorenu diskusiju, Ford se mogao uveriti u spremnost Jugoslavije da sačuva svoju nezavisnost u odnosu na SSSR i da se odupre tendencijama u pokretu nesvrstanosti koje su išle $u$ prilog pretvaranju tog pokreta u privezak Istočnog bloka.

${ }^{57}$ Zajednička jugoslovensko-američka izjava, Borba, 5. avgust 1975. 
Dragan Bogetić

THE VISIT OF THE GERALD FORD TO YUGOSLAVIA, AUGUST 1975 AND THE YUGOSLAV-AMERICAN DISPUTES

OVER THE ACTUAL WORLD AFFAIRS

\section{Summary}

The diplomatic talks held between the Yugoslav President Tito and the US President Ford, were the important step in the mutal relations between the two countires burdened with issues of the political affiars in so-called Third Worls. Being one of the founder of the Non-alligned movememt, the Socialist Yugoslavia widely criticised the American foreign policy in the Middle East, towards the crisis in Cyprys, Panama and Chile, and on the American influence on the global economical system. It was also, the first meeting between two presidents. During the talks Tito stressed that he will not use his leading role within the Non-alligned Movement as the tool of the pro-Soviet Bloc, but that he will act as meditator between the United States and Middle East countries in solving of the mutual misunderstanding and crisis. On the other side, Presindent Ford ensured the Yugoslav counterpart that there will be no steps in US foreign policy towards the Soviet Union, which may provoke the position of Yugoslavia. Ford firmly stressed the Ameircan support for the Yugoslav independent and nonalligned policy. He promissed further financial agrangments and aid for Yugoslavia, as well as postive outcome related on the Yugoslav request for some military purchases in the United States. 